\title{
Undergraduate Research on Sight Translation: Implications for Interpreter Training ${ }^{1}$
}

\section{Tradução oral à Prima Vista: Pesquisa discente e implicações para a formação de intérpretes}

\author{
Glória Regina Loreto \\ Sampaio
}

\begin{abstract}
This paper focuses on the results of four undergraduate research subprojects linked to a major ongoing project on sight translation, of which the writer hereof is the author and leader. The subprojects, conducted at the Catholic University of São Paulo and sponsored by the Institution's Teaching and Research Authority, looked into specific aspects of sight translation from the viewpoint of translation/interpretation students, trainers and practicing professionals. The results obtained so far provide a fresh insight into the complexities of sight translation and the challenge it poses to professionals-in-the-making, with substantial scope for pedagogical considerations regarding interpretation/ translation training programs.
\end{abstract}

Keywords: Sight translation; undergraduate research; translator and interpreter training.

Resumo: Este artigo aborda os resultados de quatro subprojetos de pesquisa de Iniciação Científica, atrelados a um projeto maior de autoria docente e ainda em andamento. As pesquisas discentes, que tiveram lugar na PUC-SP sob a orientação desta autora e com o patrocínio da Comissão de Ensino e Pesquisa da referida

\footnotetext{
${ }^{1}$ This paper is based on an oral presentation at a Round-Table on Research in Interpreting, during SIMBI - The 1st. Brazilian Symposyum on Interpreting Studies, held at the University of São Paulo in September, 2013, and on an oral presentation at the Boston 2011 ATA Annual International Conference.
} 
SAMPAIO; G. R. L. - Undergraduate Research on Sight Translation: Implications for Interpreter Training

instituição, debruçaram-se sobre aspectos específicos e complementares da Tradução Oral à Prima Vista (TrPV), segundo a perspectiva de alunos, professores e profissionais da tradução e interpretação. Os resultados obtidos até o momento trazem subsídios sobre os desafios impostos pela TrPV, com desdobramentos para a os programas de formação de tradutores e intérpretes.

Palavras-chave: Tradução oral à prima vista; pesquisa discente na graduação; formação de tradutores e intérpretes.

\section{Preamble}

Sight translation (STr) is the oral rendition of a written text at first sight.

Although less frequent in conference interpreting than the other modes of oral translation (GILE 2009), and so far attracting modest attention from interpreting studies researchers (J IMENEZ 1999), STr is indubtably an essential part of an interpreter's professional competence (HURTADO-AlBIR 2001, PÖCHHACKER 2004).

At the same time, STr in its different modalities (J IMENEZ 1999) makes for a complex mental exertion which requires concentrated attention, specific textual processing skills and a cognitive load by no means inferior to that of other oral translation modes (GILE 1995, 2009; SYYSNUmmi 2003; AgRIFOLIO 2004; LAMBERT 2004; J AKOBSEN \& J ENSEN 2008; ChMiel 2010).

Considering that the reading and oral translation of the written text occur concomitantly, that is, "the interpreter's target-text production is simultaneous not with the delivery of the source text but with the interpreter's real-time (visual) reception of the written source text" (PÖCHHACKeR 2004: 19), STr has consistently been seen as a variety or special 2type of simultaneuous interpretation (HERBERT 1952; PÖCHHACKER 2004). 
SAMPAIO; G. R. L. - Undergraduate Research on Sight Translation: Implications for Interpreter Training

These considerations and the firm belief that for its complexity and specificities STr provides an ample room for reflection about its nature and its role in translator/interpreter training (SAMPAIO 2007, 2009, 2011) have motivated the main project from which the subprojects referred to herein emerged.

\section{The Research}

The topic under dicussion herein are the results of four undergraduate research subprojects on STr, which stem from an ongoing main research project on the interfaces between theoretical and practical aspects of STr Translation (SAMPAIO 2007).

The objetives of the main project encompass an investigation of (i) the role of STr in the development and refinement of translation/interpretation skills; (ii) different approaches to STr teaching methodology; (iii) STr in terms of its relevance in the professional life of translators and interpreters.

Drawing on the results obtained and to be obtained, the ultimate objective of the main project is to bring to light some aspects of STr, and possibly to propose a STr teaching methodology model.

Under the supervision of the leading researcher and author of the main project, the four undergraduate research subprojects were developed by students attending the BA in Translation Course and the Non-Degree Course in Conference Interpreting offered by the Catholic University of São Paulo.

The students involved received a modest endowment from the Teaching and Research Authority of the Catholic University of São Paulo.

The first two subprojects were developed concurrently from 2007 to 2008. The other two were developed consecutively from 2008 to 2009 and from 2009 to 2010, respectively. The students involved in the research work were: subproject 1: SERINo 2008; subproject 2: FerReIRA De Jesus 2008; subproj ect 3: SANTOS 2009; and subproject 4: TESCH 2010. 
Evidently, what is presented in this paper represents an overview of the four undergraduate researches. For a more comprehensive and detailed description, each one of the subprojects should be read.

\section{Theoretical Foundations}

Two main theoretical principles provided the necessary conceptual framework for the development of the study, namely (i) Interpretive Theory of Translation (Théorie du Sens) (SeleSKovitch \& Lederer 1989, 2002 ), and (ii) the Effort Models Theory (GILE 1995, 2009).

The four undergraduate researchers studied these theoretical propositions, which provided the necessary tools for the analysis of the data collected and subsequent preliminary conclusions.

\section{Focus}

Subprojects 1 and 2 investigated STr from the point of view of translation/interpretation students. Subproject 3 looked into STr from the point of view of translation/interpretation trainers. Subproject 4 probed into STr from the point of view of translation/interpretation professionals.

\section{Method}

Data collecting for the four subprojects included recordings of students' sight translations (subprojects $1 \& 2$ ); responses to an open-ended 
SAMPAIO; G. R. L. - Undergraduate Research on Sight Translation: Implications for Interpreter Training

question and to tailor-made questionnaires, taking into account the specific research questions of each subproject.

Data analysis was carried out in the light of the aforementioned theoretical principles, and more specifically in the case of subprojects $1 \& 2$ taking into account that, amongst other requirements, the STr of a given text "should sound as if the interpreter were merely reading a document written in the target language" (ANGelelLI 1999: 27).

The methodological approach was empirical, qualitative and comparative.

\section{The Students' View}

Subproject 1 (SERINO 2008) and subproj ect 2 (FERREIRA DE J ESUS 2008) focused on the challenges presented by STr from Portuguese into English, taking into account (i) the concurrent cognitive phases of the STr process (grasping sense $\Rightarrow$ deverbalisation $\Rightarrow$ message reformulation) (SELESKOVITCH AND LEDERER 1989, 2002); and (ii) the cognitive efforts that involved the STr process (reading comprehension/ memory/ coordination/ production) (GILE 1995, 2009).

While subproject 1 (SERINO 2008) looked into the challenges presented by STr of two short quasi-technical/scientific texts, subproject 2 (FERREIRA DE J ESUS 2008) looked into the challenges presented by STr of two short ordinary texts on topical issues/ current affairs.

\section{Research Questions}

The research questions for subprojects $1 \& 2$ were devised cooperatively and are as follows: 
SAMPAIO; G. R. L. - Undergraduate Research on Sight Translation: Implications for Interpreter Training

1. Did students manage to focus their attention on the sense of the source message and produce the reformulated target STr text accordingly? Did they seem to have deverbalised?

2. What elements may have facilitated grasping the sense of the source text?

3. Were there difficulties? What sort of difficulties were they? What cognitive efforts may have accounted for such difficulties?

4. To what extent did background knowledge and previous preparation affect the quality of the rendition?

5. To what extent did factors such as pronunciation, rhythm, fluidity and voice quality contribute either positively or negatively to the intelligibility of the rendition?

Subprojects 1 and 2 involved the participation of a group of volunteer subjects and the performing of a STr task, which was recorded, transcribed and analysed, taking in consideration the aforementioned Research Questions.

In addition to the recording of the STr, participants' opinions and personnal comments were obtained immediately after the completion of the STr task by means of a recorded answer to an open-ended question, and written answers to a specific questionnaire. Combined, these three elements provided the necessary data for analysis.

The recordings of the STr task happened in the Language Laboratory of the English Department of the Catholic University of São Paulo.

On the whole, fourteen volunteers participated, seven for each subproject. The volunteers were students attending the Non-Degree Conference Interpreting Course from the Catholic University of São Paulo. All of them had previous experience with doing STr in class. 
SAMPAIO; G. R. L. - Undergraduate Research on Sight Translation: Implications for Interpreter Training

On the day before the STr was done, participants were informed by email about the topic/area the STr texts would be about. It was recommended that some previous research should be done.

Before doing the STr, participants were given five minutes to prepare the STr of two short texts.

In the case of subproject 1 (SERINO 2008), the texts chosen for STr were quasi-technical/scientific texts in the area of human sciences (infectious diseases), similar in density, style and register to other texts ordinarily used in class.

The first text was about bird flu and the second about the dengue fever, as follows:

\section{Text 1: BIRD FLU}

The spread of bird flu may be waning but the world must keep up its guard against the threat of a human influenza pandemic, which is almost certain in the longer term, senior health experts said on Thursday.

Senior international bird flu experts meeting at the Anti-Avian Influenza conference in Paris said the rise in the number of cases both in birds and in humans had slackened, especially since the start of this year.

"The disease is weakening. It does not mean it could not come back but there is something happening," Bernard Vallat, head of the World Animal Health Organization (OIE), told Reuters.

The highly pathogenic H5N1 bird flu strain that appeared in Asia at the end of 2003 has infected 309 people around the globe, killing 187.

Data for the first half of 2007 might indicate the disease was coming closer to the end of a cycle, but worries remained over Indonesia, Nigeria and Egypt.

"If those last pockets were crushed it would be much more reassuring, "Bernard Vallat said. 
SAMPAIO; G. R. L. - Undergraduate Research on Sight Translation: Implications for Interpreter Training

\section{Text 2: DENGUE}

Dengue viruses are transmitted to humans through the bites of infective female Aedes mosquitoes. Mosquitoes generally acquire the virus while feeding on the blood of an infected person. After virus incubation for 8-10 days, an infected mosquito is capable, during probing and blood feeding, of transmitting the virus, to susceptible individuals for the rest of its life. Infected female mosquitoes may also transmit the virus to their offspring by transovarial transmission, but the role of this in sustaining transmission of virus to humans has not yet been delineated.

Humans are the main amplifying host of the virus, although studies have shown that in some parts of the world monkeys may become infected and perhaps serve as a source of virus for uninfected mosquitoes. The virus circulates in the blood of infected humans for two to seven days, at approximately the same time as they have fever; Aedes mosquitoes may acquire the virus when they feed on an individual during this period.

In the case of subproject 2 (FerReIRA De J ESUS 2008), the texts chosen for STr focused on topical issues/current affairs. Once again, the texts were similar in density, style and register to texts ordinarily used in class.

The first text was about global warming and the second about icebergs, as follows:

\section{Text 1: GLOBAL WARMING}

Global warming is a complex phenomenon, and its full-scale impacts are hard to predict far in advance. But each year scientists learn more about how global warming is affecting the planet, and many agree that certain consequences are likely to occur if current trends continue. Among these:

Melting glaciers, early snowmelt and severe droughts will cause more dramatic water shortages in the American West. 
SAMPAIO; G. R. L. - Undergraduate Research on Sight Translation: Implications for Interpreter Training

Rising sea levels will lead to coastal flooding on the Eastern seaboard, in Florida, and in other areas, such as the Gulf of Mexico.

Warmer sea surface temperatures will fuel more intense hurricanes in the southeastern Atlantic and Gulf coasts.

Forests, farms and cities will face troublesome new pests and more mosquito-borne diseases.

Disruption of habitats such as coral reefs and alpine meadows could drive many plant and animal species to extinction.

\section{Text 2: ICEBERGS}

Icebergs that break off Antarctica and drift away turn out to be hotspots of life in the cold southern ocean, researchers report.

Climate warming has led to an increase in the number of icebergs breaking away from the Antarctic in recent years, and a team of researchers set out to study the impact the giant ice chunks were having on the environment.

The melting ice also dumps particles scraped off Antarctica into the ocean, providing a pool of nutrients that feed plankton and tiny shrimp like creatures known as krill.

Indeed, the researchers led by Kenneth L. Smith Jr., of the Monterey Bay Aquarium Research Institute in Moss Landing, Calif., found an increase in life forms surrounding a pair of icebergs they studied.

By promoting life surrounding them, the icebergs also may have an impact on reducing the excess carbon in the atmosphere - at least somewhat countering the greenhouse warming that helped make them break free in the first place, Smith suggested.

After the STr task was completed, participants recorded their answer to the following open-ended question: What was your greatest difficulty (if any) when sight translating the texts?

Participants also answered a questionnaire, in which they commented on the quality of their rendition taking into account elements of importance 
in STr (world knowledge, specific knowledge and previous research/grasping sense and reformulation in the target language/cognitive efforts/voice quality, rhythm and fluidity).

\section{Results}

The analysis of the data collected in subprojects $1 \& 2$ showed that:

1. none of the participants succeed in sight translating at a professional level (Cf. ANGELeLLI 1999);

2. most participants felt they had vocabulary limitations (lack of previous preparation/general and specific knowledge), particularly in the quasi-technical/ scientific texts;

3. vocabulary difficulties, lack of preparation and knowledge caused many participants to expend far too much energy on the Reading Compreension Effort at the expense of the Production Effort;

4. vocabulary difficulties, lack of preparation and lack of general/specific knowledge caused them to focus their attention on words and structures of the source texts rather than on sense (even in the case of the topical issues). Two participants commented that "it was difficult to translate the English structure into Portuguese", which attests to the fact;

5. deverbalisation was difficult to achieve and many participants produced inadequate "literal" renditions.

6. irregular rhythm, hesitation phenomena, poor fluidity were present in most renditions. 
SAMPAIO; G. R. L. - Undergraduate Research on Sight Translation: Implications for Interpreter Training

\section{The Trainers' View}

Subproject 3 (SANTOS 2009) focused on STr from the point of view of translation/interpretation trainers, taking into account theoretical, practical and methodological aspects.

Five experienced teachers from leading higher education institutions in São Paulo and Rio de J aneiro agreed to participate in the research.

Participants were interviewed personally or by email.

\section{Research Questions}

The Research Questions for subproject 3 were:

1. To what extent are translator/interpreter trainers familiar with STr? Do they teach STr to their students?

2. How relevant do they consider $\mathrm{STr}$ in the training of future translators/ interpreters?

3. What conceptual views do they hold about STr? How do they perceive/ define the cognitive phases of the STr process?

4. Are their STr lessons based on any theoretical and/or practical considerations?

5. What sort of methodology do they adopt? Why?

6. In their opinion, what are the most recurrent challenges of STr classes? What factors account for the difficulties faced by students?

\section{Questionnaire}

Based on the research questions, a questionnaire was devised, as follows:

1. In your undergraduate days or when preparing to become a translator/ interpeter trainer, did you have contact with STr? 
SAMPAIO; G. R. L. - Undergraduate Research on Sight Translation: Implications for Interpreter Training

2. How relevant do you think STr competence is for future translators/ interpreters?

3. Do you do STr exercises with your students? If so, why and how often?

4. What are your conceptual views of STr? How would you define the cognitive phases of the STr process?

5. Are your STr lessons based on any theoretical/practical considerations? What methodology do you adopt? Why?

6. What are the most recurrent challenges of STr classes? To what do you attribute the difficulties faced by students?

7. In what real life situations would STR competence be essential? Do you think translators/interpreters are adequately prepared to do STR should the need arise?

\section{Results}

The analysis of the data revealed that

1. none of the interviewees learned about or did STr in their undergraduate years; only one had some STr practice as part of an extension course on Translation/ Interpretation;

2. $80 \%$ of trainers had no formal training in translation/interpretation (they held B. A. Degrees in other areas);

3. all participants said they consider STr relevant in translator/ interpreter training; as for the reasons why STr is relevant answers varied considerably, as follows: (i) STr competence is required of both translators and interpreters (even bilingual secretaries should be able to do it); (ii) STr helps students develop translational "flexibility and resourcefulness"; (iii) it fosters the development of the "dual task" 
SAMPAIO; G. R. L. - Undergraduate Research on Sight Translation: Implications for Interpreter Training

ability; (iv) it intensifies short-term memory operations; (v) it contributes most positively to vocabulary acquisition; (vi) it contributes to fluency, enhances mental agility, thus students are better prepared to face professional life.

4. all participants make their students do STr exercises ( $80 \%$ on a regular basis, $20 \%$ sporadically);

5. regarding conceptual views about the nature of STR and the cognitive processes involved in STr: (i) two interviewees said they had never studied or read about it, (ii) one said STr was similar to SI ("you read the text and think about the translation... there is an alteration of the brain"), (iii) one mentioned deverbalisation; (iv) one stated that just like any translational act STr involves grasping and producing sense;

6. $80 \%$ of the interviewees had a defined methodology (developed intuitively, though). In most cases students are given a short period of preparation; the texts are selected by the trainer $(80 \%)$ or by the students (20\%); class dynamics varies a lot, but pair work is the most recurrent feature.

7. as for common challenges and problems: all interviewees mentioned vocabulary limitations in both languages involved; $80 \%$ mentioned lack of cultural, general or specific knowledge (poor repertoire); $20 \%$ inhibition; $20 \%$ a lot of noise in the classroom.

8. concerning the relevance of STr vis-à-vis translation/ interpretation market demands: $80 \%$ consider STr competence very important and $20 \%$ relatively important;

9. regarding to what extent professionals-in-the-making are prepared to do STr in real life contexts, all interviewees stated that they are not ready to face the challenge, and suggested more emphasis be put on 
SAMPAIO; G. R. L. - Undergraduate Research on Sight Translation: Implications for Interpreter Training

the development/ refinement of STr skills. Many suggestions were given on how to achieve this.

\section{The Professionals' View}

Subproject 4 (TESCH 2010) looked into theoretical and practical aspects of STrfrom the point of view of practising translators/interpreters.

Seven seasoned professionals accepted the invitation to participate in the research.

Participants were interviewed personally or by email.

\section{Research Questions}

The Research Questions for subproject 4 were:

1. To what extent are participants familiar with STr and how often do they do STr in their professional life?

2. How relevant is STr to their professional life?

3. What professional life contexts require doing STr? What kinds of text do they have to sight translate?

4. What are the most common challenges presented by STr? What do they arise from?

5. What theoretical views do they have about STr and the cognitive process involved in it?

6. Are participants guided by theoretical or practical principles as far as STr is concerned?

7. Do they think STR should integrate the curriculum of translation/interpretation courses? Was it so then they were preparing for professional life? 
SAMPAIO; G. R. L. - Undergraduate Research on Sight Translation: Implications for Interpreter Training

\section{Questionnaire}

Once again, based on the research questions, a questionnaire was devised:

1. How relevant is STR to your professional life?

2. How often do you have to do STr in professional translation/ interpretation contexts?

3. What sort of real life situations require doing STr? What sort of texts do you usually have to sight translate?

4. What are the greatest challenges of STr? Why?

5. Do you have any theoretical views about the cognitive processes involved in STr?

6. When doing STr are you guided by any theoretical or practical principles?

7. Do you think translation/interpretation courses should include STr in their curriculum?

\section{Results}

The analysis of the data showed that

1. all participants were familiar with STr (and its varieties);

2. all of them stated STr competence is not only relevant but of fundamental importance both in consecutive or simultaneous interpreting contexts;

3. $86 \%$ said $\operatorname{STr}$ was highly frequent in their professional life; $14 \%$ declared that the most common variety was STr in SI contexts ('sight 
SAMPAIO; G. R. L. - Undergraduate Research on Sight Translation: Implications for Interpreter Training

interpretation' or 'simultaneous interpretation with text' ); $14 \%$ said STr was not required so frequently;

4. as for the situations that required STr, 67\% mentioned conferences and focus groups, 33\% mentioned court interpreting or quase-judicial interpretation contexts;

5. regarding the types of text to be sight translated, academic papers read out by the speaker, CVs and résumés, presentation slides, banns, antenuptial agreements and vital statistics certificates were considered the most recurrent texts;

6. the greatest challenges posed by STr: [40\%] keeping up with the speed of the speaker's discourse (in the case of simultaneous interpretation with text); [20\%] the complexities of the written language; [20\%] keeping calm under pressure; [20\%] being capable of looking ahead along the text for the next unit of meaning and using your prediction skills while sight translating the previous chunk;

7. $86 \%$ of participants considered their theoretical knowledge of STr insufficient; as for the cognitive phases or efforts involved in the process, $62 \%$ said STr demanded reading and interpretation strategies; $13 \%$ the ability of detecting units of meaning;

8. the guiding principles adopted included: concentration skills (25\%); accummulated experience (25\%); the ability to simplify information (25\%); adequate allocation of cognitive efforts (13\%);

9. all participants emphasised the need of a STr component in translator/ interpreter training programmes;

10. $13 \%$ of participants commented on the paucity of materials and literature on STr vis-à-vis its importance in professional practice. 
SAMPAIO; G. R. L. - Undergraduate Research on Sight Translation: Implications for Interpreter Training

\section{Conclusions}

Although the findings are limited to specific circumstances and cannot be generalised since further studies of similar nature should be carried by other researchers with similar interests and compared with the data arising from the investigation herein described, the results achieved so far suggest that:

1. translation/interpretation students must be provided with wider opportunities to delevelop STr skills, alongside with motivation to enlarge their vocabulary, general knowledge and cultural repertoire;

2. the development and refinement of STr competence is essential for competent professional practice;

3. translation/interpretation trainers should pursue the ideal of continuing education in order to be better prepared to provide their students with theoretical and practical insights regarding the complexities of the different translational modes intrinsic to professional practice, which includes STr;

4. further investigation of different aspects of STr is necessary, particularly into some more recurrent and complex STr varieties, such as 'sight interpretation';

5. STr studies and investigation should result in publications, so that translation/interpretation students, trainers and practitioners can find the necessary subsidies towards STr skills acquisition and competence refinement, improved teaching methodologies and better professional practice. 
SAMPAIO; G. R. L. - Undergraduate Research on Sight Translation: Implications for Interpreter Training

\section{References}

AGRIFOGLIO, M. Sight Translation and Interpreting: a comparative analysis of constraints and failures. Interpreting Volume 6:1. Amsterdam/ Philadelphia: J ohn Benjamins Publishing Company, 2004, p. 43-67.

AngelelLI, C. The Role of Reading in Sight Translation. The ATA Chronicle. Volume XXVIII, May 1999. Alexandria, VA: 1999, p. 27-30.

Chmiel, A. Interpreting Studies and psycholinguistics. In: Gile, D., HANSEN, G. \& POKORN, N.K. (editors). Why Translation Studies Matters. Amsterdam/ Philadelphia: J ohn Benjamins Publishing Company, 2010, p. 223235.

FERREIRA De J ESUS, J.D. Tradução Oral à Prima Vista do inglês para o português no contexto do profissional em formação: da apreensão do sentido à reformulação e produção textual de assuntos de atualidade. São Paulo: Pesquisa de Iniciação Científica. Orientador: G R L Sampaio, PUC-SP, 2008.

GILE, D. Basic Concepts and Models for Interpreter and Translator Training. Amsterdam/ Philadelphia: J ohn Benjamins Publishing Company, 1995.

Basic Concepts and Models for Interpreter and Translator Training.

Revised Edition. Amsterdam/Philadelphia: John Benjamins Publishing Company, 2009.

Herbert, J. The Interpreter's Handbook - How to Become a Conference Interpreter. Genève: Librarie de L'Université, Georg \& Cie S.A., 1952.

HuRTADO-AlBiR, A. Traducción y Traductología. Madrid: Ediciones Cátedra, 2001.

J AKOBSEN, A.L. AND J ENSEN, T.H. Eye movement behaviour across four reading tasks. In: GöPfeRICH, S., J AKOBSEn, A. L., MeES, I, M. Looking at eyes - Eyetracking Studies of Reading and Translation Processing. Denmark: Copenhagen Studies in Language 36, Samfundslitteratur, 2008, p.101-121.

J IMÉNEZ, A. La Traducción a la vista. Un Análisis descriptivo. Tesis Doctoral. Universitat Jaume I, Facultat de Ciències Humanes i Socials. Castellón, Espanha, 1999.

LAMBERT, S. Shared Attention during Sight Translation, Sight Interpretation and Simultaneous Interpretation. META. Volume 49, numéro 2, J uin 2004. 
SAMPAIO; G. R. L. - Undergraduate Research on Sight Translation: Implications for Interpreter Training

PÖCHHACKER, F. Introducing Interpreting Studies. London and New York: Routledge, 2004.

SAmPAIO, G.R.L. A Tradução Oral à Prima Vista: aspectos teóricos, práticos e teórico-práticos e interfaces com o ensino-aprendizagem da Tradução e da Interpretação. Projeto de Pesquisa cerfiticado pela Comissão de Ensino e Pesquisa da PUC-SP e cadastrado no CNPq. São Paulo, 2007.

Mastering Sigh Translation Skills. In: Tradução \& Comunicação - Revista Brasileira de Tradutores № 16. São Paulo: Unibero/Anhaguera Educacional, 2007, p. 63-69.

Sight Translation Step by Step. In: Different Approaches to Interpreter Training. USA: ATA NYC Conference Proceedings, 2009.

Exploring the Interface: Sight Translation in Translator and Interpreter Training. In: Actas V Congreso Latinoamericano de Traducción Interpretación. Buenos Aires: CTBA Editorial 2011.

SAnToS, L.A. A Tradução Oral à Prima Vista na perspectiva do professor de tradução/ interpretação: aspectos teórico-práticos e metodologia. São Paulo: Pesquisa de Iniciação Científica. Orientador: G R L Sampaio, PUC-SP, 2009.

Seleskovitch, D. \& LedereR, M. A Systematic Approach to Teaching Interpretation. Translated by Jacolyn Harmer. First published in French as Pédagogie Raisonnée de L'Interprétation, by the Office for Official Publications of the European Communities, Luxembourg and Didier Erudition, Paris. European Communities, 1989, p. 21-26.

Pédagogie raisonnée de l'interprétation 2e. edition corrigée et augmentée. France: Didier Érudition - Office des publications officielles des Communautés Européennes, 2002, p. 205-214.

SERINO, P.H. Tradução Oral à Prima Vista do inglês para o português no contexto do profissional em formação: da apreensão do sentido à reformulação de textos de caráter técnico e científico. São Paulo: Pesquisa de Iniciação Científica. Orientador: G R L Sampaio, PUC-SP, 2008.

SYYSNUmmi, L. Cognitive Load During Sight Translation - an Experimental Study. Master's Degree Dissertation. Finland: University of Turku, 2003.

Tesch, G.B. A Tradução Oral à Prima Vista: a teoria e a prática do ponto de vista do tradutor e/ou intérprete profissional. São Paulo: Pesquisa de Iniciação Científica. Orientador: G R L Sampaio, PUC-SP, 2010. 